\title{
Making the Americas: U.S. Business People and Latin Americans from the Age of Revolutions to the Era of Globalization
}

Thomas O'Brien

University of Houston

\begin{abstract}
U.S. business people have played a central role in shaping the relationship between the United States and Latin America. Their ambitious transportation, mining, and plantation projects had dramatic economic and political effects on the nations of the Circum-Caribbean during the nineteenth century. In the course of the past one hundred years, American corporations have extended their activity throughout South America, affecting not only economic development, but attempting to alter the work habits and consciousness of millions of Latin Americans, and providing an important catalyst for both mass political movements in the region and U.S. interventions.
\end{abstract}

From eighteenth-century New England whaling men and merchant adventurers to twenty-first-century CEO's of multinational corporations, U.S. business people have played a central role in shaping the relationship between the United States and Latin America. In fact, it can reasonably be argued that no American institution has had a more persistent and profound influence on the region than U.S. business. American entrepreneurs were among the first to record eyewitness accounts of Latin America for their fellow citizens in the eighteenth century. Their ambitious transportation, mining, and plantation projects had dramatic economic and political effects on the nations of the Circum-Caribbean during the nineteenth century. In the course of the past one hundred years, American corporations have extended their activity throughout South America, affecting not only economic development, but attempting to alter the work habits and consciousness of millions of Latin Americans, and providing an important catalyst for both mass political movements in the region as well as U.S. interventions. American business has had truly profound effects upon the region and the perceptions which Latin Americans have of this country, its people, and themselves.

Among the earliest American visitors to Latin America were colonial merchants who carried on a lively, albeit illegal, trade with Spain's Western 
Hemisphere colonies. Violating the rather porous trade monopoly that Spain had imposed on her colonies, Yankee merchants traded regularly with nearby Spanish possessions, especially the island of Cuba. New England merchants not only traded fish and lumber for molasses, they also played a vital role during the frequent wars on the European continent, as they carried European goods to colonies in the Western Hemisphere while their mother countries were locked in combat with one another. As a result, Spain's colonies alone accounted for 40 percent of U.S. exports by 1807. ${ }^{1}$ American colonial merchants did not just barter for goods, they also traded in ideas. Convinced that the United States represented the new Jerusalem with a mission to bring its version of Christianity to the world, American merchants regularly brought copies of Protestant Bibles to Latin America hoping to share their religious insights with what they viewed as the 'benighted' Catholics of the region. Merchants also took on a more secular and political mission. Richard Cleveland, a merchant from Salem, Massachusetts and his fellow New Englander, William Shaler, sailed on a mercantile venture to Chile in 1801. But the men had more than barter on their minds. With anti-imperial sentiment spreading through the Spanish colonies, Cleveland and Shaler brought along copies of the U.S. Declaration of Independence which they shared with Chileans, while offering encouraging words about the benefits of independence. ${ }^{2}$

Commercial ventures also helped shape Americans' and Latin Americans' perceptions of each other. Whaling men who often spent considerable amounts of time in Latin American ports during their voyages into the south Atlantic and the Pacific, came away with some very specific ideas about Latin America which they shared through sea chanteys that recounted their alleged dalliances with mysterious and romantic Latin women and their accounts of the raw and powerful forces of nature they experienced on the coast of South America. At the same time, American merchants' stories of Latin America's potential wealth helped prompt their government to promulgate the Monroe Doctrine in 1823. The Doctrine attempted to reserve a special role for the United States in Latin American affairs and the region's future development. In turn, Latin Americans often developed their first impressions of Americans from the sailors and merchants they encountered on their streets. The sometimes raucous behavior of sailors and whaling men did not leave the best of impressions on their hosts, but these fleeting images were often the only impressions which the people of the Americas had of one another in the early nineteenth century. ${ }^{3}$ But the interactions between American entrepreneurs and Latin Americans would eventually grow more intense and bring additional knowledge to both sides.

Despite the early American merchants' heady visions of wealth to be won in Latin America, trade relations within the Americas suffered a series of serious setbacks by the 1820s. The end of the Napoleonic Wars in 1815 sharply curtailed America's trade with its southern neighbors as European 
countries reenacted restrictions on trade with their Western Hemisphere colonies and provided serious competition for American merchants in the region. Latin American wars for independence starting in 1810 disrupted trade, and did long term damage to local economies. Because of these factors, and the considerable economic power of Great Britain, American merchants soon found Latin American trade dominated by British mercantile houses. But these reversals did not end economic ties to Latin America. ${ }^{4}$ Instead U.S. entrepreneurs took new initiatives, focused on direct investment in the area.

The seizure of vast Mexican territories in the West and Southwest added hundreds of thousands of Mexicans to the U.S. population, and the gold rush in California attracted thousands of additional Latin Americans, giving impetus to a process of Latin Americanization of the United States that would continue into the twenty-first century. Of a more immediate consequence, those events made finding a more viable route to the West than trekking across the plains or the long and dangerous sea voyage around Cape Horn an urgent national priority. Central America presented itself as the most logical site for such a route. In 1848, the U.S. Senate approved a treaty with the government of New Granada (Colombia), giving the United States the right to establish a transit way across the Panamanian isthmus. The American government also supplied subsidies for carrying the U.S. mail to George Law's United States Mail Steamship Company and William Aspinwall's Pacific Mail Steamship Company. These firms provided steamer transport between the Atlantic and Pacific coasts of the United States and Panamanian ports. ${ }^{5}$ The success of the ventures soon attracted competition from shipping magnate Cornelius Vanderbilt.

In 1848, Vanderbilt secured a concession for a transit way across Nicaragua which when linked with his ocean-going ships would allow him to move freight and passengers between the east and west coasts of the United States and compete with the companies operating in Panama. ${ }^{6}$ But Vanderbilt's enterprise soon ran afoul of an American with his own ambitions in Nicaragua.

In 1855, William Walker, a sometime journalist, led a small band of American mercenaries to Nicaragua to join rebels challenging the government. Walker toppled the existing regime and installed himself in power. He transferred the transit concession to two of Vanderbilt's former business partners, prompting Vanderbilt to support Walker's opponents, contributing to the demise of Walker's government in $1857 .^{7}$

In William Walker's failed challenge to the power of Cornelius Vanderbilt could be glimpsed part of the future of inter-American relations. While the mercenary military ventures for private empire building of Walker and others enjoyed no more than fleeting success, the business initiatives of Vanderbilt and scores of lesser-known entrepreneurs had profound and lasting effects upon the relations between the United State and its southern neighbors. One of the most important examples of such investments was the rail line built across the Isthmus of Panama. 
From the moment that William Aspinwall received a government subsidy for his Pacific Mail and Steamship Company, he entertained the possibility of building a railroad across the isthmus. In 1850, Aspinwall along with two partners, Henry Chauncey and the intrepid traveler John L. Stephens, established the Panama Railroad Company. Originally, the entrepreneurs expected to complete the project in six months. In fact, swamps, snakes, mosquitoes, intense heat, and humidity, as well as disease, slowed progress to a snail's pace. The company laid the final length of track in 1855. For all the euphoria that accompanied its opening, the railway had cost the lives of John L. Stephens and six thousand workers. Despite the appalling losses, the railway proved an immediate success with tens of thousands of North Americans crossing the isthmus each year, thanks to rapid rail transportation. Along with this infusion of American technology appeared other outcroppings of American culture. Enterprising U.S. citizens built hotels, saloons, and restaurants at the terminal points of the railway to provide passengers with the food, drink, and services they were accustomed to at home. ${ }^{8}$ But the success of the railway did not mean that American initiative would be warmly welcomed on the isthmus. A number of areas of friction quickly developed between Americans and Panamanians. The efficiency of the railway deprived boatmen, and muleteers of their livelihoods, and Panamanians who lacked necessary skills saw jobs with the railway going to immigrants, especially Jamaicans. Conflict between Americans and locals also derived from fundamental cultural conflicts.

Americans held deeply disparaging attitudes toward people of color that seemed to intensify in their contact with Panamanians. The competitive, hard driven, materialistic values of Americans clashed continuously with the values of Panamanians as the railway, other American enterprises, and a flood of American travelers brought rapid change to isthmian society. These clashes between the two societies soon erupted into violence. In Panama City, on the evening of April 15, 1856, a dispute between a drunken American and a local fruit peddler escalated into a riot. Hundreds of local residents poured into the streets, attacking American travelers and an array of U.S. owned businesses, including hotels and the railway station. Approximately twenty people, mostly Americans, died before the violence subsided. ${ }^{9}$ Even at this relatively early stage American direct investment and the presence of a growing number of Americans were having a profound influence on Latin America, although local reactions were not always negative or violent.

The changes that American enterprise wrought were particularly notable in Cuba. The sugar trade had drawn the two economies together ever more rapidly during the first half of the nineteenth century. American trading houses provided new sources and methods of financing for Cuban planters, and they came to serve as business training programs for the ambitious children of the Cuban bourgeoisie. American technology had 
a powerful influence as American steam-powered equipment transformed production methods in Cuban sugar mills. By mid-century American equipment had provided 600 miles of railway. U.S.-built steamers linked the island to its northern neighbor, and an American introduced the first telegraph system. With U.S. technology, came American engineers, machinists, and technicians to operate the new machinery. Although relatively few in number at first, American entrepreneurs also began to acquire sugar plantations and mining ventures. None of these enterprises commanded the kind of position and influence of the railroad company in Panama, but the cumulative effect of U.S. technology, enterprise, and citizens proved just as profound. Members of the Cuban middle class came to accept the fact that economic development depended on adopting or adapting American technology and education as well as American values such as competitiveness, and market-oriented problem solving. Cubans came to realize that the colonial system could not cultivate but only constrain development of an economy that was increasingly being shaped by American influences. ${ }^{10}$ At the same time, Cubans had a direct influence on the United States as Cuban business people traveled north to establish enterprises ranging from merchant houses to cigar factories. In Mexico, where there was also a significant American business presence, the reactions to American business activity were heavily influenced by that country's past experience as a target of U.S. territorial ambitions.

Among the earliest American business people to involve themselves deeply in Mexico was the Connecticut-born merchant Charles Stillman. Stillman arrived in Matamoros in 1828 to market goods from his father's firm in New York. Over the next quarter century, Stillman built a business empire in northeastern Mexico that included cotton exporting, mining ventures, ranches, and farms. Allied with Stillman in many of his ventures were Miflin Kenedy and Richard King, two entrepreneurs who acquired vast landholdings in southern Texas and northern Mexico. In 1850, the three men provided financial backing to General José María Carbajal's invasion of Mexico, in a failed attempt to create the 'Republic of the Sierra Madre' that would give them political control of the northeastern portion of Mexico which they already dominated economically. ${ }^{11}$

By the 1850s, American businessmen in Mexico enjoyed the support of Mexican Liberals who were rising to power. Liberals such as President Benito Juárez viewed U.S. trade and investment as important elements in promoting Mexico's development. Yet, the Liberals were also painfully aware that the secession of Texas and the war with the United States in 1846 had cost their country over one-half of its national territory. As a result, Juárez and his successor, Sebastian Lerdo de Tejada, chose a cautious approach to American investment initiatives, especially the building of railroads. A particular sore point was the effort of New Orleans businessmen to secure a railway concession across Mexico's Isthmus of Tehuantepec to tap into the California trade then flowing across Panama and Nicaragua. ${ }^{12}$ 
The unwillingness of Juárez and other moderates to open Mexico fully to such U.S. investment would eventually lead to the ousting of the moderates by an alliance of radical Liberals and U.S. business interests that propelled Porfirio Díaz to power.

While American investment initiatives were largely confined to the Circum-Caribbean before the Civil War, a few farsighted Yankee entrepreneurs ventured further south, most notably the American railroad builder, William Wheelwright. Coming to South America in 1823, Wheelwright soon conceived a vision for the future development of the continent, a future that would be built on a transportation grid of transcontinental railroads, steamships, and telegraph lines. Wheelwright himself made prodigious efforts to fulfill that dream. He founded the Pacific Steam Navigation Company in 1840 to link Peru, Bolivia, and Chile, later extending steamer service to Panama. The American entrepreneur helped improve the water supply system and installed electric lighting in Chile's main port of Valparaiso, built the country's first railroad, and developed the port of Caldera. During the 1860s, Wheelwright became the guiding force behind the Central Argentine Railway Company that laid the principal rail line in northwestern Argentina. Yet, despite Wheelwright's prodigious accomplishments, he was one of only a handful of U.S. investors that had a significant impact in South America before the Civil War. Even Wheelwright's 'American' ventures such as the Chilean railroad, the Pacific Steam Navigation Company, and the Central Argentine Railway Company depended on financial backing from London in the absence of funding from the incipient capital markets of the United States. ${ }^{13}$ Ultimately, British capital and technology would control the railways of South America, and until the end of the nineteenth century, British economic domination of the region would not be seriously challenged. Yet, Wheelwright's ventures and vision clearly reflected a continued belief by American business people that they were destined to play the pivotal role in the development and general uplift of Latin America.

In the short term, the visions of William Wheelwright and other American entrepreneurs would be frustrated in part by the British and by the Civil War which tore American society apart. For five years, the nation's economic energies flowed into the war. In its aftermath, state policies such as protectionist tariffs and support for railroad building created an array of investment opportunities that maintained a focus on the domestic economy for the next two decades. Nevertheless, developments in both the United States and Latin America created the preconditions for an explosive growth in U.S. business activity in Latin America.

By the end of the nineteenth century, the second industrial revolution with its technologies of mass production created intense price competition among U.S. manufacturers who produced essentially the same uniform goods. As a result, American industrialists sought both new markets and cheaper raw material inputs from overseas. These factors spurred U.S. 
trade with Latin America, as the value of American exports to the region jumped from $\$ 93$ million in 1890 to $\$ 263$ million in 1910 . Over roughly the same time frame, direct U.S. investment increased from $\$ 300$ million to $\$ 700$ million as American firms applied their new technologies and business practices to mining and plantation ventures, especially in the Cirum-Caribbean. ${ }^{14}$ The beginnings of what would become an explosive growth in trade and investment in the region was due only in part to developments in the U.S. economy.

U.S. companies found themselves welcomed with open arms by Liberal political leaders such as Porfirio Díaz of Mexico and Augusto Leguía of Peru. Much like the Cuban bourgeoisie, Liberal politicians had come to accept the American paradigm that development depended on infusions of U.S. capital and technology, and implementation of market driven strategies. Many of these early experiments enjoyed striking success. Thanks in no small part to U.S. investments that improved production and transportation efficiency, Mexico's exports grew by an average of 4.5 percent annually between 1883 and 1913, while Central American exports increased annually by 3.7 percent during the same period. ${ }^{15}$ U.S. corporations also contributed to the creation of a modern working class as they employed a variety of techniques and institutions from task systems to company stores in efforts to discipline a labor force that was resistant to the enticements and rigors of wage labor.

Leading the process of investment growth were the Guggenheim brothers and their mining enterprises in Mexico and Chile, the United Fruit Company's banana plantations in Central America, and Standard Oil's petroleum ventures in Mexico, Peru and Venezuela. The Guggenheim enterprises that included their American Smelting and Refining Company in Mexico and the Braden Copper Company as well as the Chuquicamata and El Teniente mines in Chile applied the newest mining technologies. Their Chuquicamata operation, for example, used mass extraction and refining techniques to turn low grade copper ore deposits into one of the largest and most successful copper mines in the world. Standard Oil tapped the oil resources of the region by applying levels of technology and capital concentration that were not available in local economies. United Fruit, while far less technologically advanced than mining and petroleum operations, used capital and transportation technologies including railroads and steamships, coupled with a highly effective marketing operation in the United States, to dominate the banana industry in Latin America. ${ }^{16}$

By the 1920s manufacturers of consumer goods and providers of consumer services also entered the region. General Electric (G.E.) which operated within what we would call today a 'high tech' sector, relied on protection of its patent rights as a way of controlling markets and fending off competitors. Partly with that in mind, the company entered the power generation business in Latin American as the American and Foreign Power 
Company. By the 1920s, G. E. executives had come to appreciate the profit potential of the consumer market and they were soon selling radios, electric irons and washing machines in nearly a dozen different Latin American countries. International Telephone and Telegraph (ITT) began operations in Puerto Rico and Cuba, and by 1930 had holdings in ten different Latin American countries. ${ }^{17}$

The success of U.S. corporate investors and the growth in trade with Latin America would not have been possible without the considerable assistance of American financial institutions. Bankers like J. P. Morgan and National City Bank's James Stillman who had followed his father Charles into Latin America, helped bankroll the Guggenheims, G. E. and dozens of other enterprises in the region. ${ }^{18}$ They also floated loans to Latin American governments helping them fund infrastructure development and continue importing goods even in difficult economic times. By 1914, U.S. bank loans to Latin America stood at $\$ 350$ million and thanks in part to the First World War which dried up European capital markets, that figure exploded to $\$ 1.5$ billion by $1929 .{ }^{19}$ Not all of this growth derived from private initiatives.

The federal government had historically opposed intervening in the private sector. However, the United States became increasingly interested in stabilizing and reforming certain regimes within its sphere of influence. Under its policy of Dollar Diplomacy, the state began brokering loans from U.S. investment houses for countries such as the Dominican Republic and Nicaragua. The government effectively guaranteed those loans while requiring the recipients to accept U.S. financial advisors who were given broad financial powers such as customs collection. In the minds of U.S. policy makers and these 'money doctors,' financial stability would throw these economies open to increased market influences, leading to greater economic efficiency and instilling discipline, and productivity in their populations. ${ }^{20}$ International finance had become a new means of achieving the American mission of reform in Latin America.

Communications and transportation represented additional areas where the U.S. government gave a boost to U.S. business in Latin America. Thanks to exclusive contracts for carrying the U.S. mail, Yale graduate Juan Trippe launched Pan American Airways. With these monopolistic contracts and ties to firms such as United Fruit and W. R. Grace, Pan American came to dominate air service from Cuba through most of South America during the 1920s. A similar coalition assured a powerful U.S. position in radio. With the prodding and assistance of President Woodrow Wilson, G. E., United Fruit, Western Electric, and American Telephone and Telegraph joined together to create the Radio Corporation of America (RCA) which in a few short years became a dominant force in Latin American radio. By the 1940s, RCA was beaming U.S.produced programming and advertising into millions of homes in Latin America. The American film industry enjoyed similar growth in the region 
as World War I dried up the supply of European films. By 1935, Latin America had more than 4500 movie theaters, and U.S. companies produced 70 to 80 percent of the films being shown at the cinemas. Those films presented powerful images of American material wealth and technological achievements along with strong affirmations of the positive influence of American competitiveness. ${ }^{21}$ But despite the penetration of American media, the proliferation of brokered loans, the success of large U.S. corporations, and impressive rates of economic growth in many Latin American countries, all was not well with American enterprise in the region.

The racist views which had characterized American perspectives on Latin Americans by the middle of the nineteenth century had not dissipated a half century later. While Americans believed that they could and would improve the lot of most Latin Americans, they also believed that their neighbors were racially inferior beings who required the civilizing efforts of North Americans. Such beliefs only added to the friction between American managers and the working and middle class Latin Americans whom they believed must be transformed into approximate versions of their North American counterparts. Part of this process involved imposing the disciplines of modern capitalist enterprise on workers, subjecting them to long hours of work, and strict supervision to which most of them were unaccustomed. In labor-intensive enterprises like banana and sugar plantations that discipline meant extracting as much physical labor in as short a time as possible. While capital-intensive undertakings like G. E. required more skilled labor and therefore provided education and health benefits to ensure a well-trained and stable work force, they too were intent on close supervision of workers, and attempted to transform both blue collar and white collar workers into individualistic, highly competitive employees much like the work force they had nurtured at home. U.S. corporations subjected their workers to a variety of influences designed to achieve this goal. They attempted to substitute American movies for the social drinking and gambling habits of their workers, hoping to ensure sobriety in the workplace, and commitment to the Protestant work ethic. Corporate-sponsored baseball and basketball teams promoted values of individualism and competitiveness. American companies encouraged marriage among their workers to create nuclear family units which they believed would foster worker stability, and a future generation of employees dedicated to the corporation, and devoted to hard work. ${ }^{22}$ Such efforts at Americanization that were frequently tainted by racist views that deemed Latin Americans to be fundamentally inferior, triggered growing resentment among the middle and working classes in the region. That resentment was further exacerbated by conditions within Latin American societies.

Latin America's liberal regimes of the early twentieth century can be most easily characterized by the motto emblazoned on the national flag of Brazil: 'Order and Progress.' Put slightly differently, the elites of these 
countries pursuing their foreign assisted development dreams were determined that popular protest and unrest would not divert them from their course. They continued high levels of labor repression that kept rural as well as urban wages at extremely low levels and created acute economic disparities. The Liberal governments of the era built their economies on the export of one or two agricultural or mineral products. These types of goods were subject to sharp price gyrations on the world market, making it difficult to sustain economic growth over the long term. Furthermore, many of the industries producing these products, especially foreign owned enterprises, had few linkages to the local economy, and therefore failed to stimulate the development of domestic enterprises. From the perspective of much of the working and middle classes, the elite regimes and their allies, the American corporations, had either created or perpetuated poverty, repression and erratic economic performance in their societies. ${ }^{23}$ By the 1920s the signs of militant resistance had become all too apparent to U.S. corporate executives.

One of the most striking examples of resistance to American corporate penetration erupted in 1910 as the forces of revolution swept across Mexico. Despite the economic growth that American investment helped stimulate, Mexicans at all levels of society had come to resent President Porfirio Díaz's liberal treatment of U.S. corporations. Members of the elite and the middle class feared that their own enterprises would be overwhelmed by the flood of foreign investment. Peasants rebelled against policies that stripped them of land that was then exploited by U.S. companies, and workers found themselves subjected to new and more onerous working conditions in American enterprises. ${ }^{24}$ Similar if less spectacular upheavals shook several Central American countries over the next two decades as United Fruit and its competitors became targets of angry strikes and protests by workers, peasants, and middle class entrepreneurs. Typically these movements enabled popular forces to rally around a nationalist platform that denounced foreign exploitation and the support which local elites had provided to the Americans. ${ }^{25}$ Corporate leaders learned little from these experiences, choosing to rely on friendly local governments or U.S. military might to deal with the problems. But repressive measures would ultimately prove to be woefully inadequate when American businessmen faced economic collapse and social upheaval in their Latin American venues.

Although Americans typically date the start of the Great Depression from October 1929, signs of the impending global economic collapse had been mounting rapidly in Latin America well before that date. By the late 1920s the prices for agricultural and mineral products that served as the backbone of the region's export economies, had begun a steady downward slide. Improved transportation and production technologies, which U.S. corporations had brought to the region, were contributing to a global glut for these products, pushing a number of Latin American economies into depression by 1928. Americans corporations were shaken to their 
foundations as prices nosedived and capital markets shriveled. Daniel Guggenheim's grand plan to create a total monopoly over the Chilean nitrate industry faltered, and then disintegrated delivering a massive blow to the global mining empire he and his brothers had built. ${ }^{26}$ U.S. companies across Latin America radically reduced their activities and fired workers en masse, or reduced their wages to starvation levels. Latin American governments faced rapidly declining revenues just as the U.S. financial crisis was depriving them of loans from New York banks that helped them weather earlier slumps in their export sectors. Disastrous economic conditions triggered waves of social upheaval across the region. ${ }^{27}$

The edifice of elite liberal regimes that had governed much of Latin America for more than half a century came tumbling down as the Great Depression set off a series of social and political earthquakes. A combination of military coups and populist political movements swept aside the old order. While these movements varied widely, the populist parties typically energized middle and working class groups, along with peasants, in movements that targeted foreign investors and the elite as the chief culprits in the economic debacle. These movements called for elimination or regulation of foreign investment and state intervention to ensure economic recovery and a more equitable distribution of wealth. In one of this era's most dramatic episodes, President Lázaro Cárdenas nationalized Mexico's foreign-controlled oil industry in $1938 .^{28}$

U.S. corporations had to adjust to these rapidly changing realities. Although their conversion was often a grudging one, executives began showing an increased sensitivity toward Latin American nationalism by the 1940s and 50s. The most progressive corporations such as G. E. instituted programs to hire more locals into mid level management positions, improve living conditions for workers and went to great lengths to portray themselves as partners with the state in the project of national development. The U.S. government also played a leading role in this process, with its Good Neighbor Policy that stressed non-intervention and economic policies designed to revive trade and investment in the Western Hemisphere. The American state took on an increasingly important role in managing business relations with Latin America. No longer content to simply impose financial, diplomatic or military pressure at moments when U.S. corporations found themselves in peril, instead the U.S. state sought to prevent such drastic measures. ${ }^{29}$

The Great Depression and the populist movements it helped trigger also lead to dramatic changes in state economic policies in Latin America. Governments imposed increased taxation on U.S. corporations and an array of social laws that required companies to provide additional benefits and protections to their employees. A growing number of states adopted import-substituting economic strategies. In the years after World War II, the United Nation's Economic Commission on Latin America (ECLA) provided the intellectual underpinnings for this approach to development. 
The Commission and especially its director, the Argentine economist Raúl Prebisch, argued that the terms of trade in Latin America's exchange of primary products for manufactured goods were unfavorable to Latin America and stifled its own industrialization. Import substitution offered an alternative to the U.S. development paradigm that stressed the liberalization of markets. Import substitution policies built protectionist barriers, particularly against consumer imports, as part of a larger state effort to promote domestic industrialization. ${ }^{30}$ These policies did not intend to discourage foreign direct investment, indeed they encouraged it. U.S. corporations adapted to these changing conditions by increasing direct investment as a way to circumvent the trade barriers that had been put in place. That shifting strategy also marked an important change in the composition of American investment.

American corporations that represented the traditional sectors of U.S. investment such as mining and agriculture returned to prosperity during and after World War II, and total U.S. investment rose from $\$ 3$ billion in 1940 to $\$ 8.3$ billion in 1960 . As of 1929 , manufacturing constituted only 8 percent of direct U.S. investment in Latin America. But between 1943 and 1960 , manufacturing investment rose from $\$ 340$ million to $\$ 1.3$ billion or 12 percent of total investment. ${ }^{31}$ Manufacturing rapidly became the fastest growing segment of U.S capital flows to the region. Consumer industries played an important part in this growth. Companies like Coca Cola that had already spent several decades trying to build a base in Latin America now had an opportunity to exploit the new protectionist barriers and the return to prosperity which World War II brought. Coca Cola had launched marketing efforts in Mexico and South America during the 1920s, but these initiatives collapsed during the Great Depression. However, by the end of World War II, the company had developed strong markets in Mexico and Brazil. American auto-makers like General Motors and Ford had also been early entrants into the Latin America market, but they limited their operations to assembling vehicles from imported parts. By the early 1960s they had manufacturing operations in Mexico, Brazil, and Argentina, largely due to efforts by those countries' governments to create domestically-based auto industries. ${ }^{32}$ The growing role of these brand-name manufacturers also drew an icon of the American consumer economy to the region. The J. Walter Thompson Company, America's best-known advertising agency, had followed leading corporate clients like General Motors to Latin America during the 1930s. Thompson and other U.S. advertising agencies helped bring the techniques of American marketing and the values of American consumerism to the region, although those efforts initially focused on the elite and the small middle class whose members could afford U.S. products. ${ }^{33}$

The change in the composition of U.S. investments was not due entirely to the success of manufacturers. Part of that shift reflected growing problems for other types of U.S. corporations. American utilities, 
especially the American and Foreign Power Company and ITT found themselves under increasing pressure as Latin American governments regulated rates and imposed foreign exchange controls. Those conditions threatened their profitability and led both companies to plan on divesting themselves of their Latin American interests. Another area which did not enjoy a rebound at this time was banking. At the start of the Depression, Latin American governments had defaulted on more than $\$ 1$ billion in loans from U.S. banks. Over the next decade and a half, the holders of the bonds issued for the loans worked out a series of debt restructuring agreements with Latin American governments that drastically reduced the total of the debt and therefore the returns on those loans. That experience left American financial institutions leery of new credit extensions to Latin America. Here the U.S. government stepped in, loaning more than $\$ 1.5$ billion to the region between 1948 and 1955. Much of that lending was carried out through multilateral agencies that the United States had constructed. ${ }^{34}$ In fact, the American government had been busy building both multilateral and national institutions through which it could extend its influence in Latin America.

By the 1950s, the American state possessed an impressive array of agencies through which it could affect conditions in Latin America. These included multilateral organizations such as the World Bank that supported infrastructure development projects; and the International Monetary Fund (IMF) that managed debt and stabilized currencies, essentially institutionalizing the activities of the "money doctors" of an earlier time. Internally, the federal government now had the Export Import Bank to make loans to facilitate trade, the Agency for International Development which funneled foreign aid, the United States Information Agency for propaganda, and if worse came to worst, the Central Intelligence Agency (CIA) for covert operations. These agencies provided instruments for pursuing a particular U.S. strategy for the region.

The Great Depression forged an alliance among the federal government, capital-intensive corporations, and labor unions. This alliance stressed both progressive labor policies and internationalist economic initiatives that would promote American trade and investment around the globe. The key to the alliance and its ability to articulate a social, economic, and political paradigm that shaped American society for the next half century was its focus on the concept of productivity. The stress on the ability to achieve ever-greater levels of economic efficiency welded the business-labor coalition together through the belief that the United States could propel its economy to new heights of prosperity without having to redistribute economic power. Furthermore, efforts by business and government to combat the Depression and win World War II brought business leaders into state agencies, and created a consensus on the use of interventionist planning as a critical means to achieve productivity improvements and create a more stable form of capitalist development. ${ }^{35}$ 
The broad alliance now had an ideology focused on a planned capitalist process which would achieve economic growth and general prosperity while avoiding class conflict. That shared vision would both guide and limit the alliance's project of Americanizing Latin America.

While the United States government took a more activist role in the region with loans and development grants, the ultimate purpose of these strategies was to promote private sector solutions to the region's difficulties, particularly solutions provided by U.S. corporations. As the sources of the productivity improvement that drove the American economy while avoiding class conflict, U.S. corporations were touted as the logical solution to Latin America's problems of underdevelopment.

No individual more clearly personified this new alliance and its sense of mission than Nelson Rockefeller. One of the heirs to the massive Rockefeller/Standard Oil fortune, Rockefeller took a deep interest in Latin America during the 1930s and became convinced that Standard and other U.S. corporations must adopt more progressive policies in response to Latin American labor unrest and rising nationalism. During the war, Rockefeller served as the head of the Office of Inter-American Affairs, and later as Assistant Secretary of State for Latin American Affairs. In these posts, Rockefeller launched an aggressive campaign to burnish the image of the United States in the region, and to promote economic development projects. After leaving government service he established two organizations, one for profit, and one non-profit designed to promote private initiatives in Latin America that would encourage development and serve as examples of the progressive corporate policies he had embraced. ${ }^{36}$ Meanwhile, during the 1950s and 60s, the U.S. government increasingly adopted policies promoting public health, agricultural efficiency and improved education that would serve the needs of Latin American development and U.S. business interests. Despite these strategies, trouble was rapidly brewing for U.S. business.

The 1960s and 70s would be marked by revolutionary struggles and political movements giving vent to strong anti-American sentiments. Numerous U.S. enterprises would face nationalization. A variety of factors created this hostile environment. Despite the populist movements of the 1930s and 40s, acute disparities in economic wealth and political power still marked Latin American societies. Although U.S. corporate executives and government bureaucrats believed that American investments could generate powerful increases in productivity, their equally strong commitment not to tamper with acute inequalities in social and political power meant that economic advances would not be equitably shared within Latin American societies. U.S. businesses became closely identified with the elites who still dominated these nations, and they along with the elites became targets of movements seeking social and economic justice. And while some American corporations had developed more progressive policies towards their managers and workers, U.S. entrepreneurs still viewed 
Latin Americans as inferior to themselves and treated them accordingly. At the same time, Latin American nationalists decried the domination of key sectors of their economies by American corporations. These factors combined to trigger a variety of nationalist and leftist movements that challenged American corporate interests.

During the early 1950s the reformist government of Guatemalan President Jacobo Arbenz instituted labor codes and land reform measures that threatened the interests of United Fruit until a CIA-backed plot toppled the regime in 1954. In 1959, the revolutionary government of Fidel Castro initiated a process that led to the expropriation of $\$ 1$ billion in U.S. investment in Cuba. In 1970, Salvador Allende, the newly elected Socialist president of Chile began a similar process until he fell victim to a CIA-assisted military coup in 1973. Even in countries with more conservative political regimes U.S. companies often faced difficult going. The Great Depression had created a strong sense of economic nationalism throughout the region, and in particular resentment of foreign domination of the region's natural resources. As a result mining and petroleum enterprises in countries such as Venezuela and Peru faced nationalization during this period. ${ }^{37}$ Despite corporate reforms and strong assistance from the U.S. government, American corporations found themselves under siege by the mid 1970s. However, events were about to dramatically alter this hostile environment.

A series of military coups such as the one in Chile, crushed the radical and even revolutionary popular movements that had shaken the region's political institutions for more than a decade. The new military rulers provided a far more favorable environment for American business. Brazil, where a military coup halted populist unrest in 1964, served as a model for revised strategies of import substitution that soon influenced both military and civilian governments in the region. The Brazilian regime created a three-way partnership among state corporations, private domestic companies and foreign corporations. At the same time, the state pursued policies that effectively froze wages and shifted income toward the middle and upper classes to create a larger domestic market for consumer durables such as automobiles. To avoid one of the most serious problems facing import-substituting regimes - a sharp decline in exports - the government used a series of mechanisms such a tax credits and exchange controls to encourage the export of industrial goods. These policies allowed American corporations including General Motors, G. E. and their foreign competitors to dominate key sectors such as automobiles and electrical parts. The Brazilian government still retained a strong nationalistic element in its policies expanding its control of utilities and petroleum, while protecting domestic corporations in other sectors of the economy. ${ }^{38}$ With Brazil's new version of import substitution producing impressive rates of economic growth, Mexico and Argentina adopted similar strategies that offered low cost labor and other inducements for foreign companies to enter specific parts of the manufacturing sector. 
In these countries as well, strong nationalist sentiment excluded U.S. and other foreign corporations from some sectors of the economy. Nevertheless, the environment was highly favorable to American corporations as U.S. investment in Latin America increased by 250 percent between 1970 and 1981. Manufacturing played the key role in this rapid expansion, with that sector now accounting for more than 40 percent of U.S. holdings. ${ }^{39}$

Although natural resources and manufacturing remained the key elements in U.S. investment, American corporations also entered new fields. By 1968, Latin Americans owned nearly 10 million television sets, and the American Broadcasting Company held interests in local stations with a total audience of 20 million households. Even more impressively, U.S. broadcasters produced 80 percent of the programming shown in the region. Although this dominance in programming would not last, television did offer a major new opportunity for American corporations to promote American values through commercials and programs. ${ }^{40}$

As fresh opportunities appeared for American corporations in Latin America, many firms instituted new workplace policies to increase productivity. The approach, known as Fordism, after Henry Ford, combined high wages, assembly line production and scientific management techniques. Workers faced a constant stream of time-motion studies that led to continuing revisions in the work process and ever-closer supervision. Protests against these procedures resulted in dismissal with little opportunity for appeal. ${ }^{41}$ As the 1970 s came to a close, more hostile work environments, increasing disparities in income distribution and faltering domestic economies prompted a wave of popular protest in Latin America against the new economic strategies. Beneath that wave of social and political unrest, a financial time bomb was ticking and about to explode.

U.S. banks, which had largely avoided Latin America after the Great Depression, now battled each other for lending opportunities. By the mid 1970s, U.S. payments on its trade and budget deficits, and funds flowing from oil producers enjoying the rapid run up in petroleum prices swelled the coffers of international financial institutions with billions of dollars. U.S. banks, such as Citibank and Bank of America, seeking profitable uses for this ocean of capital found willing customers among Latin American states with their array of development projects. In just over ten years, Latin America's foreign debt increased more than ten-fold. The dizzying debt ride came to a screeching halt when a recession in the United States adversely affected international trade, making it increasingly difficult for Latin American economies to earn foreign exchange to meet their international obligations. In 1982, Mexico found itself unable to make its debt payments, threatening a crisis that could topple the leading U.S. banks and the international financial system.

The banks rescheduled Latin American debts to prevent defaults that could destroy their own institutions. But such measures provided only a stopgap solution. For the longer term, Latin American governments 
had to accept drastic measures dictated by the IMF that included slashing social welfare expenditures and reducing imports in order to set aside funds for debt repayment. These policies triggered a decade of economic contraction and falling real wages. But unlike the response to the Great Depression, this period of economic disaster would actually open the doors wider than ever before for U.S. corporations in Latin America. ${ }^{42}$

Latin American governments, in fact, had few options in responding to the debt crisis. First, unlike the Depression, the debt crisis was not a global phenomenon meaning that creditors and creditor nations could treat the area's debt problems in isolation without fear of defaults around the globe. Second, with the decline of the Soviet Union, these countries lacked alternate sources of international financial assistance. And third, many of the regions leading technocrats had been trained in U.S. universities or in programs sponsored by the U.S. government and private foundations. Steeped in the traditions of capitalist orthodoxy, these economic specialists were strongly inclined to seek free market solutions that favored hefty new infusions of foreign capital. The prevailing wisdom in government circles argued that Latin America's economic woes, stemmed from the protectionist import-substituting policies of the past which had led to excessive economic regulation, slowed exports, and discouraged foreign investment. Latin America was about to enter on a new, neo-liberal era of economic policy-making that would be highly favorable to U.S. corporate investment. ${ }^{43}$

In the age of neo-liberalism at the end of the twentieth century, Latin American governments reduced export and import barriers, rolled back regulation of foreign corporations and began privatizing state enterprises. Privatization was not merely a part of the new economic strategy; it was often set as a condition by the IMF for extensions of credit to Latin American nations that were staggering under enormous debt burdens. Foreign investors were offered debt equity swaps, allowing holders of the national debt to exchange it for positions in domestic enterprises. The process of liberalization sent U.S. investment flowing into service sectors including telecommunications, energy, transportation and banking, as well as natural resources sectors once under state control. Most of this investment surge went to Brazil, Mexico, Argentina, Chile, Colombia and Venezuela; with Brazil and Mexico capturing the lion's share of this capital. The most common form of investment centered on acquiring existing assets. In the early 1990s that involved the purchase of privatized state enterprises. Many of the state enterprises created during the nationalistic fervor of the Great Depression were auctioned off to domestic and foreign bidders. In Argentina, for example, foreigners invested more than $\$ 4.7$ billion between 1990 and 1993 in public entities in petroleum, petrochemicals, telecommunications, electricity and railroads that were being privatized by the government. During the 1990s, the sale of Latin American utilities generated $\$ 220$ billion, often resulting in improved 
technologies and services. By the turn of the century, new investment focused on acquiring private local companies. In 2001, Citibank, now known as Citigroup, the U.S.'s largest financial conglomerate, purchased Mexico's second largest bank, Grupo Financiero Banamex Accival, for $\$ 12.5$ billion, making it the largest foreign acquisition ever by a U.S. bank, and making Citigroup the largest financial institution in Mexico. ${ }^{44}$

The initial success of neo-Liberalism in Latin America was undeniable. During the 1990s inflation in the region dropped from 200 percent annually to under 20 percent. Between 1990 and 1998, annual U.S. exports to Latin America soared from $\$ 53.9$ billion to $\$ 142$ billion. Imports from Latin America climbed from $\$ 67$ billion to $\$ 142$ billion. U.S. direct investment more than tripled from $\$ 70.7$ billion in 1990 to $\$ 223$ billion in 1999. In almost a replay of liberalization a century earlier, these changes were characterized by increased investments in the natural resource sector, especially energy. U.S. petroleum firms lead by the largest corporations such as Exxon, Mobil and Chevron doubled their expenditures on exploration and development between 1987 and 1994. During the decade of the 90s, banking and manufacturing showed strong growth. Investments in finance alone more than quadrupled to $\$ 124$ billion and holdings in the manufacturing sector doubled to $\$ 51$ billion. Particularly notable was a surge in investment by the big three automakers, GM, Ford and Chrysler as they poured capital into improved technologies and plant expansion, seeking to maintain their competitiveness in the world market, and expand their position in regional markets. At the same time, U.S. corporations like Bell South entered new fields such as mobile phone systems. In sharp contrast to the 1960s when official aid programs accounted for 70 percent of U.S. capital flowing to Latin America, in the 1990s private investment accounted for 90 percent of those transfers. The rewards to corporate America proved substantial. The income of U.S. firms and their subsidiaries from Latin America totaled $\$ 5.7$ billion in 1990 , climbing to $\$ 14.6$ billion in $1997 .{ }^{45}$

Meanwhile, the North American Free Trade Agreement (NAFTA) initiated a series of reciprocal tariff reductions among the United States, Mexico, and Canada over a fifteen year period. The trade agreement had a positive effect on the trade between the United States and its southern neighbor. From 1994 to 2000, agricultural trade between the two countries increased by 55 percent, reaching $\$ 11.6$ billion annually. Overall trade between Mexico and the United States increased from $\$ 100$ billion in 1994 to $\$ 170$ billion in 1998. However, the long-term impact of NAFTA was hotly debated in all three nations. Critics charged that hundreds of thousands of jobs had been lost in the United States, and that increased agricultural trade largely benefited multinational agribusinesses rather than small farmers. Supporters claimed that low-wage jobs were shifting to Mexico to produce inputs such as car engines which were then exported to the U.S. for assembly by high-wage auto-workers. 
Largely dismissing the criticism, U.S. officials sought to make NAFTA the basis for a regional free trade zone. In April 2001, 34 western hemisphere leaders met in Quebec City, Canada, for the Summit of the Americas. President George W. Bush gave strong backing to the creation of the Free Trade Area of the Americas (FTAA) which would create a free trade pact encompassing 800 million consumers in the western hemisphere. The summit members called for the creation of the FTAA by 2005. But the U.S. effort to expand the NAFTA model to the entire hemisphere still faced difficult going. Part of the opposition stemmed from some of the leading industrial powers such as Brazil and Argentina who feared that their manufacturers would wither under competition from the U.S. Brazil also insisted that it must receive access to the highly protected U.S. agricultural sector. ${ }^{46}$ Furthermore, free trade agreements which did little to protect workers and the environment triggered a growing anti-globalization movement around the world. Millions of Latin Americans began to express mounting doubts about the panacea of prosperity which the United States government and business leaders had argued would flow from aggressive free trade policies. There were growing concerns about whether trade liberalization could in fact bring self-sustaining economic development and relieve the region's deep-seated poverty.

Despite the surge in U.S. investment, unemployment rates in Latin America rose during the 1990s, real wages fell and income distribution worsened. As a result, 35 percent of the region's people remained trapped in abject poverty - just as they were two decades earlier. With their economies growing at rates of 3 or 4 percent annually, Latin American nations did not generate the kind of growth that would lift the majority of their populations beyond the level of mere subsistence. In fact, these rates fell considerably below the 5.5 percent growth rate that the region's economies averaged during the state driven development decades of the 1950s and 60s. Meanwhile, years of hyperinflation, bankruptcies and the slashing of government social spending had devastated the middle class. Protestors from small business people to workers and peasants made a direct connection between their woes and the increased penetration of their economies by U.S. business. The economic disruptions spurred another form of protest as new waves of Latin American immigrants surged northward in search of jobs, accelerating a long but increasingly rapid Latin Americanization of the United States.

These expressions of discontent remained relatively subdued during the early and mid 1990s when most of the economies of Latin America enjoyed positive economic growth rates. But at the end of the decade, as economic expansion slowed in the United States and much of the rest of the world, popular opposition to globalization became more vehement. The economic slow down directly impacted Latin American economies as average gross domestic product per capita declined at the turn of the century from the highs it had reached during the mid to late $1990 \mathrm{~s}^{47}$ In 
other words, the output of Latin American economies failed to keep pace with the growth of their populations. Economic setbacks in Latin America exposed fundamental flaws in the neo-liberal development model and triggered more strident, sometimes violent responses to the region's increasing incorporation into the U.S.-led process of globalization.

The neo-liberal model for growth that became the standard for development policy in Latin America in the closing years of the twentieth century, bore striking similarities to that of the liberal development schemes of the late nineteenth century. Proponents of the neo-liberal approach encouraged Third World nations to embrace the world marketplace by expanding export-led growth, focused on products in which they already specialized. For industrializing countries like Brazil and Mexico that meant increasing exports of manufactured goods from shoes to automobiles. But this strategy also suffered from some of the same flaws as its nineteenth-century predecessor. In particular, the liberalization of trade had encouraged currency outflows that weakened exchange rates as consumers rushed to acquire foreign made goods that were now cheaper thanks to reduced import duties. More importantly, many countries were encouraged to find their place in the new world economy much as they did in the old world economy, that is, by emphasizing the export of mineral resources and agricultural products. As in the past, this approach increased those economies' vulnerability to the inevitable and severe price gyrations that occur in these products. After a decade of relative prosperity under liberalized trade rules, this fundamental problem reared its head once again at the beginning of the twenty-first century as prices for key Latin exports such as coffee and copper began dropping precipitously. Even Chile, the poster child for neo-liberal reform, was not immune to such problems. By the year 2001 the world recession had driven copper prices down more than 25 percent. Dependent on copper sales for 40 percent of its annual exports, the country suffered a severe economic slowdown. ${ }^{48}$ As was the case more than a century earlier, opening the Latin American economies to the world market also made them increasingly vulnerable to the vicissitudes of world commodity markets and left them with a limited industrial base to offset the effects of setbacks in their commodity export economies. Popular responses to these problems became increasingly militant during the closing years of the twentieth century.

On January 1, 1994, the day on which NAFTA took effect, a band of armed guerrillas occupied the city of San Cristóbal de las Casas in Mexico's southeastern state of Chiapas. Known as the Zapatista National Liberation Army (EZLN), the guerrillas declared war on neo-liberal globalization. Their leader, sub commandante Marcos, put it quite simply, 'This isn't about Chiapas - it's about NAFTA and [Mexican President] Salinas's whole neoliberal project. ${ }^{49}$ The Zapatistas gave vent to growing resentment towards NAFTA and the government's neo-liberal policies 
which left peasants unable to compete with subsidized corn imports from the United States and which removed basic protections for communal land.

In Argentina, once considered a model of neo-liberal success, a peso pegged to the U.S. dollar had increased the prices of national exports, while liberalized trade policies allowed Argentineans to go on an import spending spree. Those conditions combined with excessive government spending and widespread corruption brought the national economy to its knees by the end of the twentieth century. Mass protests against the country's economic collapse in late 2001 toppled the government. ${ }^{50}$ Two years of political and economic chaos, ensued as the government defaulted on its debt and Argentineans held their own political class and the foreignowned corporations responsible for the debt crisis, and the disintegration of many small businesses.

By the beginning of the twenty-first century, Latin Americans angered by economic recession and the failure of neo-liberal experiments to address economic inequality vented their anger toward the domestic politicians and foreign investors who implemented these policies. Leftist or populist candidates such as Luis Inacio Lula da Silva, Nestor Kirchner and Hugo Chavez were elected to the presidencies of Brazil, Argentina, and Venezuela. Much as happened at the beginning of twentieth century, an era of liberal trade and investment policies had spurred a new surge of American corporate involvement, only to be followed by sharp antiAmerican reaction when economic decline occurred. But the interaction between U.S. corporations has never been a simple love-hate relationship.

The era of neo-liberal trade and privatization allowed American capital, goods and ideas to penetrate ever more broadly and deeply into Latin American societies. Particularly notable was the increasing spread of American consumer products, beyond the major urban centers and into the smallest communities of Latin America. Perhaps no product has better symbolized the penetration of American consumer goods and the values attached to them than Coca Cola. The Coca Cola Corporation has long associated its product with fundamental American ideals and cultural practices - the idea of freedom as the freedom to consume, the belief that human happiness is derived directly from such forms of consumption, and the sheer pleasures of leisure time activities and the prosperity that makes them possible. And yet the success of Coke, and for that matter other American consumer products, did not signify a simple and universal acceptance of American values by Latin Americans. Many people in Latin America believe that Coke is in fact a product of their own society. In the Argentinean Northwest, offerings of water are brought to the shrine of a local saint in soft drink bottles. In Haiti, Coke is believed to revive the dead. In other Latin American countries, it is mixed with local alcoholic beverages to make such 'national drinks' as Cuba Libras. ${ }^{51}$ In other words, as much as the consumption of these goods, may at times signify buying into certain American values, it is also true that these goods are integrated 
into local cultures thereby giving them new meaning. Such processes also raise interesting questions about the degree to which the people of Latin America may now constitute their identity through American/transnational commodities as opposed to national symbols. ${ }^{52}$ At the same time, increasing interaction with Latin America, along with the growing migration of Latin Americans to the United States, spurred consumption of Latin American cultural products ranging from food and music to literature and art. The case of consumer goods demonstrates that Americanization over the past century has never been a simple imposition of American technologies, work methods, products and values on Latin America. Rather, the corporate-led process of Americanization has continued to function as a complex articulation or interaction between American society and the cultures of Latin America, albeit one marked by unequal relations of power.

From Richard Cleveland's mission to spread republicanism to Nelson Rockefeller's dreams of spurring progressive corporate-led economic development, American entrepreneurs have spent more than two centuries pursuing ventures that they believed would be profitable to themselves and uplifting for their Latin American neighbors. Their enterprises have had profound effects on the material condition of the region, spurring periods of strong economic growth, transferring modern technologies and training generations of managers and politicians. Their efforts to promote the values and institutions of their own society in Latin America helped create modern industrial working and middle classes and quicken the spread of consumer culture. At the same time, American corporations' domination of key sectors of national economies, the mixed message of their Americanization of workers and managers whom they considered fundamentally inferior, and the economic downturns that have followed surges in U.S. investment, have often prompted intense anti-American reactions. Meanwhile, beneath the ebb and flow of embracing and contesting U.S. corporate influence, a more subtle interaction has taken place, as Latin Americans have refined important elements of the American corporate mission, and incorporated them into their own identity.

\section{Notes}

${ }^{1}$ J. H. Coatsworth, 'American Trade with European Colonies in the Caribbean and South America, 1790-1812', William and Mary Quarterly, 3.24(2), 1969, p. 243; J. Barbier and A. J. Kuethe (eds), The North American Role in the Spanish Imperial Economy, 1760-1819 (Manchester, Manchester University Press, 1984).

${ }^{2}$ R. F. Nichols, 'William Shaler: New England Apostle of Rational Liberty', The New England Quarterly, ix, 1936, pp. 85-95.

${ }^{3}$ For one of the best accounts of activities and impressions of North American whaling men on the coast of South America, see E. P. Salas, Los primeros contactos entre Chile y los Estados Unidos, 1778-1809 (Santiago, Editorial Andres Bello, 1971).

${ }^{4}$ D. C. North, Growth and Welfare in the American Past: A New Economic History (New York, Norton, 1966), pp. 25, 61. 
${ }^{5}$ J. H. Kemble, The Panama Route, 1848-1869 (Berkeley, University of California Press, 1943; Reprint, New York, De Capo Press Inc. 1972), pp. 1-57.

${ }^{6}$ C. H. Brown, Agents of Manifest Destiny: The Lives and Times of the Filibusters (Chapel Hill, University of North Carolina Press, 1980), pp. 222-43.

${ }^{7}$ R. E. May, The Southern Dream of Empire, 1854-1861 (Baton Rouge, Louisiana State University Press, 1973) pp. 126-131. For a highly detailed account of the same events see Brown, Agents of Manifest Destiny, pp. 244-457.

${ }^{8}$ http://www.trainweb.org/panama/history1.html; M. Chen Daley, 'The Watermelon Riot: Cultural Encounters in Panama City, April 15, 1856', Hispanic American Historical Review, 70(1), 1990, pp. 85-100.

${ }^{9}$ Chen Daley, 'Watermelon Riot', pp. 87-9.

${ }^{10}$ L. A. Pérez Jr., On Becoming Cuban: Identity, Nationality, and Culture (Chapel Hill, University of North Carolina Press, 1999), pp. 17-37.

${ }^{11}$ J. Hart, Revolutionary Mexico: The Coming and Process of the Mexican Revolution (Berkeley, University of California Press, 1989), pp. 108-12.

${ }^{12}$ M. Reed, New Orleans and the Railroads: The Struggle for Commercial Empire, 1830-1860 (Baton Rouge, Louisiana State University Press, 1966), pp. 68-69; R. Roeder, Juárez and His Mexico 2 vols. (New York, Viking Press, 1947), vol. 1, p. 232.

${ }^{13}$ J. V. Fifer, United States Perceptions of Latin America, 1850-1930: A 'New West' south of Capricorn? (Manchester, Manchester University Press, 1991), pp. 20-52. For details of Wheelwright's career see J. B. Alberdi, The Life and Industrial Labors of William Wheelwright in South America (Boston, W. Williams \& Company, 1877).

${ }^{14}$ U.S. Department of Commerce, Bureau of the Census, The Statistical History of the United States: Colonial Times to 1957 (Stamford, Conn., Fairfield Publishers, 1965), pp. 903-4; J. Wilkie (ed.), Statistical Abstract of Latin America, Vol II (Los Angeles, University of California Press, 1995), p. 821.

${ }^{15}$ V. Bulmer-Thomas, The Economic History of Latin America since Independence (Cambridge, Cambridge University Press, 1994), p. 104. On U.S. corporate efforts to create a modern work force see T. F. O'Brien, The Revolutionary Mission: American Enterprise in Latin America, 19001945 (Cambridge, Cambridge University Press, 1996), passim.

${ }^{16}$ There is no general history of U.S. business in Latin America. Although it is a broad history of U.S. enterprises overseas, Mira Wilkins pioneering two volume study provides some very valuable information on American corporations in Latin America, see M. Wilkins, The Emergence of Multinational Enterprise: American Business Abroad from the Colonial Era to 1914 (Cambridge, Harvard University Press, 1970) and The Maturing of Multinational Enterprise: American Business Abroad from 1914 to 1970 (Cambridge, Harvard University Press, 1974). For an overview of U.S. business in the nineteenth and twentieth centuries with an emphasis on their efforts at Americanization, see T. O'Brien, The Century of U.S. Capitalism in Latin America (Albuquerque, University of New Mexico Press, 1999). Standard histories of the Guggenheims include, E. P. Hoyt Jr., The Guggenheims and the American Dream (New York, Funk and Wagnalls, 1967); and H. O'Connor, The Guggenheims: The Making of an American Dynasty (1937) (New York, Arno, 1976). Other worthwhile books on U.S. mining companies in Mexico and South America include, H. F. Bain and T. T. Read, Ore and Industry in South America (1934) (New York, Arno, 1976); M. D. Bernstein, The Mexican Mining Industry, 1890-1950: A Study of the Interaction of Politics, Economics and Technology (Albany, State University of New York Press, 1965); I. Marcosson, Anaconda (New York, Dodd, Mead, 1957); F. Mallon, The Defense of Community in Peru's Central Highlands: Peasant Struggle and Capitalist Transition, 1860-1940 (Princeton, Princeton University Press, 1983). On the oil industry, useful studies include, G. Philip, Oil and Politics in Latin America: Nationalist Movements and State Companies (Cambridge, Cambridge University Press, 1982); J. C. Brown, Oil and Revolution in Mexico (Berkeley, University of California Press, 1993); E. Lieuwen, Petroleum in Venezuela: A History (Berkeley, University of California Press, 1955); and A. Pinelo, The Multinational Corporation as a Force in Latin American Politics: A Case Study of the International Petroleum Company in Peru (New York, Praeger, 1973). Good histories of United Fruit include, C. D. Kepner Jr., Social Aspects of the Banana Industry (New York, Columbia University Press, 1936); C. D. Kepner and J. H. Soothill, The Banana Empire: A Case Study in Economic Imperialism (1935) (New York, Russell and Russell, 1967). On United Fruit's chief competitor, see T. L. Karnes, Tropical Enterprise: The Standard Fruit and 
Steamship Company in Latin America (Baton Rouge, Louisiana State University Press, 1978). Another interesting study of an American corporation operating in the export sector is A. Wells, Yucatán's Golden Age: Haciendas, Henequen and International Harvester, 1860-1915 (Albuquerque, University of New Mexico Press, 1985).

${ }^{17}$ There is no history of General Electric in Latin America. Some information can be found in Wilkins, Maturing of Multinational Enterprise, pp. 65-71. ITT also lacks a book-length study of its operations in Latin America. A good company history is R. Sobel, ITT: The Management of Opportunity (New York, New York Times Books, 1982).

${ }^{18}$ For histories of leading U.S. banks see, R. Chernow, House of Morgan: An American Banking Dynasty and the Rise of Modern Finance (New York, Atlantic Monthly Press, 1990); V. P. Carosso, The Morgans, Private International Bankers, 1854-1913 (Cambridge, Harvard University Press, 1987), and H. van B. Cleveland and T. F. Huertas, Citibank, 1812-1970 (Cambridge, Harvard University Press, 1985).

${ }^{19}$ B. Stallings, Banker to the Third World: U.S. Portfolio Investments in Latin America, 1900-1986 (Berkeley, University of California Press, 1987), pp. 150-64.

${ }^{20}$ E. S. Rosenberg, Financial Missonaries to the World: The Politics and Culture of Dollar Diplomacy, 1900-1930 (Cambridge, Harvard University Press, 1999), pp. 1-60. Also see P. Drake, The Money Doctors in the Andes: the Kemmerer Missions, 1923-1933 (Durham N.C., Duke University Press, 1989).

21 E. S. Rosenberg, Spreading the American Dream: American Economic and Cultural Expansion, 1890-1945 (New York, Hill and Wang, 1982), pp. 92-7; J. Schwoch, The American Radio Industry and its Latin American Activities, 1900-1939 (Chicago, University of Illinois Press, 1990) passim; J. A. Schnitman, Film Industries in Latin America: Dependency and Development (Norwood, N.J., ABLEX Publishing Corporation, 1984), pp. 1-36, 116.

${ }^{22}$ There are several interesting studies that focus on efforts by U.S. companies to Americanize workers in Latin America. See in particular T. M. Klubock, Contested Communities: Class, Gender, and Politics in Chile's El Teniente Copper Mine, 1904-1951 (Durham, Duke University Press, 1998); P. Bourgois, Ehnicity at Work: Divided Labor on a Central American Banana Plantation (Baltimore, Johns Hopkins University Press, 1989); A. Chomsky, West Indian Workers and the United Fruit Company in Costa Rica, 1870-1940 (Baton Rouge, Louisiana State University Press, 1996); and J. L. Fine, Tracing the Veins: Of Copper, Culture and Community from Butte to Chuquicamata (Berkeley, University of California Press, 1998).

${ }^{23}$ For an overview of the period see Bulmer-Thomas, Economic History of Latin America, pp. 46-193. For case studies of national economies see, R. C. Conde and S. J. Hunt (eds), The Latin American Economies: Growth and the Export Sector, 1880-1930 (New York, Holmes and Meier, 1985).

${ }^{24}$ For this interpretation see Hart, Revolutionary Mexico.

${ }^{25}$ O'Brien, Revolutionary Mission, pp. 56-106.

${ }^{26}$ T. F. O'Brien, "Rich Beyond the Dreams of Avarice”: The Guggenheims in Chile', Business History Review, 63 (Spring), 1989, pp. 122-59.

${ }^{27}$ R. Thorp (ed.), Latin America in the 1930s: The Role of the Periphery in World Crisis (New York, St. Martin's Press, 1984).

${ }^{28}$ J. S. Herzog, Petroleo Mexicano (Mexico City, Fondo de Cultura Económica, 1941).

29 E. S. Rosenberg, Spreading the American Dream, pp. 161-210.

${ }^{30}$ Bulmer-Thomas, Economic History of Latin America, pp. 209-48.

${ }^{31}$ Wilkins, Maturing of Multinational Enterprise, p. 182.

${ }^{32}$ F. Allen, Secret Formula: How Brilliant Marketing and Relentless Salesmanship Made Coca-Cola the Best Known Product in the World (New York, Harper Collins, 1994), pp. 170-3; R. Jenkins, Transnational Corporations, and Dependent Industrialization in Latin America: The Automotive Industry in Argentina, Chile and Mexico (New York, Praeger Publishers, 1977); R. Jenkins, Transnational Corporations and the Latin American Automobile Industry (Pittsburgh, University of Pittsburgh Press, 1987); and H. Shapiro, Engines of Growth: The State and Transnational Auto Companies in Brazil (New York, Cambridge University Press, 1994).

${ }^{3}$ J. P. Woodard, 'Marketing Modernity: The J. Walter Thompson Company and North American Advertising in Brazil, 1929-1939', Hispanic American Historical Review, 82(2), 2002, pp. 257-90.

${ }^{34}$ J. F. Rippy, Globe and Hemisphere: Latin America in the Post-War Foreign Relations of the United States (1958) (Westport, Connecticut, Greenwood Press, 1972), pp. 62-89. 
${ }^{35}$ T. Ferguson, Golden Rule: The Investment Theory of Party Competition and the Logic of Money Driven Political Systems (Chicago, University of Chicago Press, 1995), pp. 113-72; and C. S. Maier, 'The Politics of Productivity: Foundations of American International Economic Policy after World War II', International Organization, 31 (Autumn), 1977, pp. 613-5.

${ }^{36}$ There are a number of interesting studies of Nelson Rockefeller's activities in Latin America including: D. Rivas, Missionary Capitalist: Nelson Rockefeller in Venezuela (Chapel Hill, University of North Carolina Press, 2002); E. H. Cobbs, The Rich Neighbor Policy: Rockefeller and Kaiser in Brazil (New Haven, Yale University Press, 1992); and G. Colby and C. Dennett, Thy Will Be Done: The Conquest of the Amazon: Nelson Rockefeller and Evangelism in the Age of Oil (New York, Harper Collins, 1995).

37 P. Gleijeses, Shattered Hope: The Guatemalan Revolution and the United States, 1944-1954 (Princeton, Princeton University Press, 1991); L. A. Pérez Jr., Cuba: Between Reform and Revolution (New York, Oxford University Press, 1988), pp. 295-305, 320-7; G. M. Ingram, Expropriation of U.S. Property in South America: Nationalization of Oil and Copper Companies in Peru, Bolivia and Chile (New York, Praeger Publishers, 1974), passim.

38 P. B. Evans, Dependent Development: The Alliance of Multinational, State and Local Capital in Brazil (Princeton, Princeton University Press, 1979) passim.

${ }^{39}$ R. F. Ramsaran, U.S. Investments in Latin America and the Caribbean: Trends and Issues (New York, St. Martin's Press, 1985), pp. 75-89.

${ }^{40}$ A. Wells, Picture Tube Imperialism? The Impact of U.S. Television on Latin America (Maryknoll, New York, Orbis Books, 1972).

${ }^{41}$ J. Humphrey, Capitalist Control and Workers' Struggle in Brazil (Princeton, Princeton University Press, 1982).

${ }^{4}$ P.-P. Kuczynski, Latin American Debt (Baltimore, John Hopkins University Press, 1988).

${ }^{43}$ For an overview of this period see Bulmer-Thomas, Economic History of Latin America, pp. 366-409.

${ }^{44}$ M. Agosin (ed.), Foreign Direct Investment in Latin America (Washington, D.C., Inter-American Development Bank and Johns Hopkins University Press, 1995) passim; World Bank Press Release No. 2002/LCR, Rio de Janeiro, Brazil, September 10, 2001; Latin American Weekly Report, May 22, 2001; and Economic Commission for Latin America and the Caribbean, 'Characteristics of Foreign Direct Investment (FDI) in Latin America', February 1999, http:// magnet.undp.org/new/pdf/PDFscomplete/ECLAC2.pdf. For case studies from the neo-liberal era see, M. Kotabe and R. P. C. Leal (eds), Market Revolution in Latin America: Beyond Mexico (New York, Pergamon, 2001).

${ }^{45}$ J. Wilkie, E. Alemán and J. G. Ortega (eds), Statistical Abstract of Latin America vol. 37 (Los Angeles, University of California Press, 2001), pp. 785, 887; http://www.citizen.org/ trade/nafta/index.cfm; M. H. Birch and G. Halton, 'Foreign Direct Investment in Latin America in the 1990s: Old Patterns, New Trends and Emerging Issues', in Foreign Direct Investment in Latin America: Its Changing Nature at the Turn of the Twentieth Century, eds. W. Baer and W. R. Miles (New York, International Business Press, 2001), pp. 18-9, 23; Energy Information Administration, 'Privatization and the Globalization of the Energy Markets', http:// www.itcilo.it/english/actrav/telearn/global/ilo/frame/energyla.htm; C. Karmin, 'U.S. sees Latin American Profits Go South', Wall Street Journal, February 12, 2003.

${ }^{46}$ M. Flynn, 'Brazil Increasingly Unenthusiastic about U.S. FTAA Proposals', American Program Analytical Article (Interhemispheric Resource Center, February 1, 2002), http:// www.americaspolicy.org/briefs/2002/0202brazil.html.

${ }^{47}$ http://www.latin-focus.com.

48 The Economist, September 29, 2001; December 1, 2001.

${ }^{49}$ Quoted in F. Jeffries, 'Zapatismo and the Intergalactic Age', in Globalization and Postmodern Politics: From Zapatistas to High-Tech Robber Barons, ed. R. Burback (London, Pluto Press, 2001), p. 129.

50 A. Acosta, 'Argentina Atrapada pro los Alquimistas', based on articles published in Hoy (Quito), Decmeber 12 and 26, 2001.

${ }^{51}$ D. Howes, 'Introduction: Commodities and Cultural Borders', in Cross-Cultural Consumption: Global Markets, Local Realities, ed. D. Howes (New York, Routledge, 1996), pp. 3-6.

${ }^{52}$ N. G. Canclini, Consumers and Citizens: Globalization and Multicultural Conflicts. Translated with an introduction by G. Yúdice (Minneapolis, University of Minnesota Press, 2001), p. 5. 


\section{Bibliography}

Acosta, A., 'Argentina Atrapada pro los Alquimistas', based on articles published in Hoy (Quito), Decmeber 12 and 26, 2001.

Agosin, M. (ed.), Foreign Direct Investment in Latin America (Washington, D.C., Inter-American Development Bank and Johns Hopkins University Press, 1995).

Allen, F., Secret Formula: How Brilliant Marketing and Relentless Salesmanship Made Coca-Cola the Best Known Product in the World (New York, Harper Collins, 1994).

Bain, H. F. and Read, T. T., Ore and Industry in South America (1934) (New York, Arno, 1976).

Alberdi, J. B., The Life and Industrial Labors of William Wheelwright in South America (Boston, W. Williams \& Company, 1877).

Barbier, J. and Kuethe, A. J. (eds), The North American Role in the Spanish Imperial Economy, 1760-1819 (Manchester, Manchester University Press, 1984).

Bernstein, M. D., The Mexican Mining Industry, 1890-1950: A Study Of The Interaction Of Politics, Economics and Technology (Albany, State University of New York Press, 1965).

Birch, M. H., and Halton, G., 'Foreign Direct Investment in Latin America in The 1990s: Old Patterns, New Trends and Emerging Issues', in Foreign Direct Investment in Latin America: Its Changing Nature at the Turn of the Twentieth Century, eds W. Baer and W. R. Miles (New York, International Business Press, 2001).

Bourgois, P., Ehnicity at Work: Divided Labor on a Central American Banana Plantation (Baltimore, Johns Hopkins University Press, 1989).

Brown, C. H., Agents of Manifest Destiny: The Lives and Times of the Filibusters (Chapel Hill, University of North Carolina Press, 1980).

Brown, J. C., Oil and Revolution in Mexico (Berkeley, University of California Press, 1993).

Bulmer-Thomas, V., The Economic History of Latin America since Independence (Cambridge, Cambridge University Press, 1994).

Canclini, N. G., Consumers and Citizens: Globalization and Multicultural Conflicts. Translated with an introduction by G. Yúdice (Minneapolis, University of Minnesota Press, 2001).

Carosso, V. P., The Morgans: Private International Bankers, 1854-1913 (Cambridge, Harvard University Press, 1987).

Chernow, R., House of Morgan: An American Banking Dynasty and the Rise of Modern Finance (New York, Atlantic Monthly Press, 1990).

Chomsky, A., West Indian Workers and the United Fruit Company in Costa Rica, 1870-1940 (Baton Rouge, Louisiana State University Press, 1996).

Cleveland, H. van B., and Huertas, T. F., Citibank, 1812-1970 (Cambridge, Harvard University Press, 1985).

Coatsworth, J. H., 'American Trade with European Colonies in the Caribbean and South America, 1790-1812', William and Mary Quarterly, 3.24(2), 1969.

Cobbs, E. H., The Rich Neighbor Policy: Rockefeller and Kaiser in Brazil (New Haven, Yale University Press, 1992).

Colby, G. and Dennett, C., Thy Will Be Done: The Conquest of the Amazon: Nelson Rockefeller and Evangelism in the Age of Oil (New York, Harper Collins, 1995).

Conde, R. C., and Hunt, S. J. (eds), The Latin American Economies: Growth and the Export Sector, 1880-1930 (New York, Holmes and Meier, 1985).

Daley, M. C. 'The Watermelon Riot: Cultural Encounters in Panama City, April 15, 1856', Hispanic American Historical Review, 70(1), 1990, pp. 85-100.

Drake, P., The Money Doctors in the Andes: the Kemmerer Missions, 1923-1933 (Durham N.C., Duke University Press, 1989).

Economic Commission for Latin America and the Caribbean, 'Characteristics of Foreign Direct Investment (FDI) in Latin America', February 1999, http://magnet.undp.org/new/pdf/ PDFscomplete/ECLAC2.pdf.

Energy Information Administration, 'Privatization and the Globalization of the Energy Markets', http://www.itcilo.it/english/actrav/telearn/global/ilo/frame/energyla.htm.

Evans, P. B., Dependent Development: The Alliance of Multinational, State and Local Capital in Brazil (Princeton, Princeton University Press, 1979). 
Ferguson, T., Golden Rule: The Investment Theory of Party Competition and the Logic of Money Driven Political Systems (Chicago, University of Chicago Press, 1995).

Fifer, J. V., United States Perceptions of Latin America, 1850-1930: A 'New West' south of Capricorn? (Manchester, Manchester University Press, 1991).

Fine, J. L., Tracing the Veins: Of Copper, Culture and Community from Butte to Chuquicamata (Berkeley, University of California Press, 1998).

Flynn, M., 'Brazil Increasingly Unenthusiastic about U.S. FTAA Proposals' American Program Analytical Article (Interhemispheric Resource Center, February 1, 2002), http://www.americaspolicy.org/briefs/2002/0202brazil.html.

Gleijeses, P., Shattered Hope: The Guatemalan Revolution and the United States, 1944-1954 (Princeton, Princeton University Press, 1991).

Hart, J., Revolutionary Mexico: The Coming and Process of the Mexican Revolution (Berkeley, University of California Press, 1989).

Herzog, J. S., Petroleo Mexicano (Mexico City, Fondo de Cultura Económica, 1941).

Howes, D., 'Introduction: Commodities and Cultural Borders', in Cross-Cultural Consumption: Global Markets, Local Realities, ed. D. Howes (New York, Routledge, 1996).

Hoyt Jr., E. P., The Guggenheims and the American Dream (New York, Funk and Wagnalls, 1967).

Humphrey, J., Capitalist Control and Workers' Struggle in Brazil (Princeton, Princeton University Press, 1982).

Ingram, G. M., Expropriation of U.S. Property in South America: Nationalization of Oil and Copper Companies in Peru, Bolivia and Chile (New York, Praeger Publishers, 1974).

Jeffries, F., 'Zapatismo and the Intergalactic Age', in Globalization and Postmodern Politics: From Zapatistas to High-Tech Robber Barons, ed. R. Burback (London, Pluto Press, 2001).

Jenkins, R., Transnational Corporations, and Dependent Industrialization in Latin America: The automotive industry in Argentina, Chile and Mexico (New York, Praeger Publishers, 1977).

Jenkins, R., Transnational Corporations and the Latin American Automobile Industry (Pittsburgh, University of Pittsburgh Press, 1987).

Karmin, C., 'U.S. sees Latin American Profits Go South', Wall Street Journal, February 12, 2003.

Karnes, T. L., Tropical Enterprise: The Standard Fruit and Steamship Company in Latin America (Baton Rouge, Louisiana State University Press, 1978).

Kemble, J. H., The Panama Route, 1848-1869 (Berkeley, University of California Press, 1943; Reprint New York, De Capo Press Inc., 1972).

Kepner Jr., C. D., Social Aspects of the Banana Industry (New York, Columbia University Press, 1936).

Kepner Jr., C. D. and Soothill, J. H., The Banana Empire: A Case Study in Economic Imperialism (1935) (New York, Russell and Russell, 1967).

Klubock, T. M., Contested Communities: Class, Gender, and Politics in Chile's El Teniente Copper Mine, 1904-1951.

Kotabe, M., and Leal, R. P. C. (eds), Market Revolution in Latin America: Beyond Mexico (New York, Pergamon, 2001).

Kuczynski, P.-P. Latin American Debt (Baltimore, John Hopkins University Press, 1988).

Latin Focus, http://www.latin-focus.com.

Lieuwen, E., Petroleum in Venezuela: A History (Berkeley, University of California Press, 1955).

Maier, C. S., 'The politics of productivity: foundations of American International Economic Policy after World War II', International Organization, 31 (Autumn), 1977, pp. 613-615.

Mallon, F., The Defense of Community in Peru's Central Highlands: Peasant Struggle and Capitalist Transition, 1860-1940 (Princeton, Princeton University Press, 1983).

Marcosson, I., Anaconda (New York, Dodd, Mead, 1957).

May, R. E., The Southern Dream of Empire, 1854-1861 (Baton Rouge, Louisiana State University Press, 1973).

Nichols, R. F., 'William Shaler: New England apostle of rational liberty', The New England Quarterly, ix, 1936, pp. 85-95.

North, D. C., Growth and Welfare in the American Past: A New Economic History (New York, Norton, 1966). 
O'Brien, T. F., "“Rich beyond the dreams of Avarice”: The guggenheims in Chile', Business History Review, 63 (Spring), 1989, pp. 122-59.

O'Brien, T. F., The Revolutionary Mission: American Enterprise in Latin America, 1900-1945 (Cambridge, Cambridge University Press, 1996).

O'Brien, T., The Century of U.S. Capitalism in Latin America (Albuquerque, University of New Mexico Press, 1999).

O'Connor, H., The Guggenheims: The Making of an American Dynasty (1937) (New York, Arno, 1976).

Pérez Jr., L. A., Cuba: Between Reform and Revolution (New York, Oxford University Press, 1988).

Pérez Jr., L. A., On Becoming Cuban: Identity, Nationality, and Culture (Chapel Hill, University of North Carolina Press, 1999).

Philip, G. Oil and Politics in Latin America: Nationalist Movements and State Companies (Cambridge, Cambridge University Press, 1982).

Pinelo, A., The Multinational Corporation as a Force in Latin American Politics: A Case Study of the International Petroleum Company in Peru (New York, Praeger, 1973).

Public Citizen, http://www.citizen.org/trade/nafta/index.cfm.

Ramsaran, R. F., U.S. Investments in Latin America and the Caribbean: Trends and Issues (New York, St. Martin's Press, 1985).

Reed, M., New Orleans and the Railroads: The Struggle for Commercial Empire, 1830-1860 (Baton Rouge, Louisiana State University Press, 1966).

Rippy, J. F., Globe and Hemisphere: Latin America in the Post-War Foreign Relations of the United States (1958) (Westport, Connecticut, Greenwood Press, 1972).

Rivas, D., Missionary Capitalist: Nelson Rockefeller in Venezuela (Chapel Hill, University of North Carolina Press, 2002).

Roeder, R., Juárez and His Mexico 2 vols. (New York, Viking Press, 1947).

Rosenberg, E. S., Spreading the American Dream: American Economic and Cultural Expansion, 18901945 (New York, Hill and Wang, 1982).

Rosenberg, E. S., Financial Missonaries to the World: The Politics and Culture of Dollar Diplomacy, 1900-1930 (Cambridge, Harvard University Press, 1999).

Salas, E. P., Los primeros contactos entre Chile y los Estados Unidos, 1778-1809 (Santiago, Editorial Andres Bello, 1971).

Schnitman, J. A., Film Industries in Latin America: Dependency and Development (Norwood, NJ, ABLEX Publishing Corporation, 1984).

Schwoch, J., The American Radio Industry and its Latin American Activities, 1900-1939 (Chicago, University of Illinois Press, 1990).

Shapiro, H., Engines of Growth: The State and Transnational Auto Companies in Brazil (New York, Cambridge University Press, 1994).

Sobel, R., ITT: The Management of Opportunity (New York, New York Times Books, 1982).

Stallings, B., Banker to the Third World: U.S. Portfolio Investments in Latin America, 1900-1986 (Berkeley, University of California Press, 1987).

Thorp, R. (ed.), Latin America in the 1930s: The Role of the Periphery in World Crisis (New York, St. Martin's Press, 1984).

Trainweb: The Panama Railroad, http://www.trainweb.org/panama/history1.html.

U.S. Department of Commerce, Bureau of the Census, The Statistical History of the United States: Colonial Times to 1957 (Stamford, Conn., Fairfield Publishers, 1965).

Wells, A., Picture Tube Imperialism? The Impact of U.S. Television on Latin America (Maryknoll, New York, Orbis Books, 1972).

Wells, A., Yucatán's Golden Age: Haciendas, Henequen and International Harvester, 1860-1915 (Albuquerque, University of New Mexico Press, 1985).

Wilkie, J. (ed.), Statistical Abstract of Latin America, Vol II (Los Angeles, University of California Press, 1995).

Wilkie, J., Alemán, E. and Ortega, J. G. (eds), Statistical Abstract of Latin America vol. 37 (Los Angeles, University of California Press, 2001).

Wilkins, M., The Emergence of Multinational Enterprise: American Business Abroad from the Colonial Era to 1914 (Cambridge, Harvard University Press, 1970). 
Wilkins, M., The Maturing of Multinational Enterprise: American Business Abroad from 1914 to 1970 (Cambridge, Harvard University Press, 1974).

Woodard, J. P., 'Marketing/modernity: The J. Walter Thompson Company and North American Advertising in Brazil, 1929-1939', Hispanic American Historical Review, 82(2) 2002, pp. 257-90.

World Bank Press Release No. 2002/LCR, Rio de Janeiro, Brazil, September 10, 2001; Latin American Weekly Report, May 22, 2001. 